\title{
初診時の $\mathrm{CT} ・ \mathrm{MRI}$ 検査で診断が困難であった 頚椎脱臼の一例
}

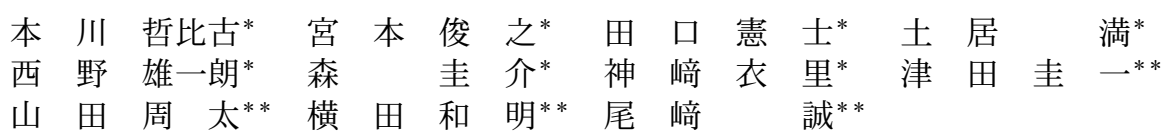

【はじめに】初診時に CT・MRI の両者を撮影したにも関わらず頝椎脱臼の診断が困難だった一例を経 験したので報告する.【症例】 84 歳男性, 脚立で作業中に転倒している所を発見され当院へ救急搬送となつ た。上肢筋力低下・徐脈などから春髄損傷が疑われたが， CT と MRI では頚椎の骨折や脱臼を認めなかつ た. 軟性装具を装着し, 受傷 1 週間程度を目処に動態撮影の予定とした. 受傷 32 時間後から上肢の麻痺 が進行し, MRIで頝椎前方脱臼を認めたため, 同日頚椎後方固定術を行った. 【考察】頝椎評価において CT は X 線より有用で, MRI は脊髄や軟部組織の描出に優れていることが知られているが, 屈曲損傷に 伴う前方脱臼では頝椎を固定して撮影する CT や MRI で脱臼が整復されることがある.このため受傷機 転や画像検査を正確に判読し，受傷後可及的早期に動態撮影で頝椎の不安定性を評価することが重要であ る.

Key words : anterior dislocation (前方脱臼), dynamic flexion and extension radiographs (動態撮 影), trauma (外傷), cervical spine injury (頝椎損傷)

\section{は じめ に}

頝椎損傷の診断遅延は麻痺を残し今後の生活の質を 落としてしまう可能性があるため, 出来るだけ早期に 適切な診断を下すことが重要である. 特に頝椎屈曲伸 延型損傷は屈曲位で頝椎に後頸部から腹側方向に外力 が加わつた時に発生し，軽傷例では初診時に脱臼が整 復されてしまい, 初診時にX 線では異常を全く認め ない症例も存在するため注意が必要である8).さらに $\mathrm{CT}^{2)} \cdot \mathrm{MRI}$ はともに骨折や脱臼，脊䯣の評価におけ る有用性が認められているが，今回我々は CT・MRI を撮像したが頝椎脱臼の診断が困難であった一例を経 験したので報告する.

$$
\text { 症例 }
$$

84 歳男性

現病歴：自宅の庭 $60 \mathrm{~cm}$ 脚立の上で䇥を掛けよう と作業していたところ, 付近の $1 \mathrm{~m}$ の階段下に仰臥 位で倒れているところを妻に発見され，当院へ緊急搬 送となった.

内服薬： $\mathrm{Ca}$ 拮抗薬， $\beta$ 遮断薬
既往歴 : 心不全, 高血圧症

外観：頭頂部に挫創あり

$$
\text { 経過 }
$$

当院へ搬送された時は腹式呼吸, 酸素 $10 \mathrm{~L}$ で $\mathrm{SpO}_{2}$ は $100 \%$ と酸素化は保たれていた. 血圧 $82 / 64 \mathrm{mmHg}$, 心拍数 40 回/分と低下していた. 意識は GCS : E4V4M6 とやや不鮮明で, 後頸部痛の有無は明らかではなかっ た. 上肢徒手筋力テスト 3 と低下を認めた. $\beta$ ブロッ カ一内服中であったが, 低血圧・徐脈, 上肢優位の麻 痺から頸髄損傷が疑われ，造影 CT（図 1)・MRI（図 2）を行った。造影 CT では明らかな頝椎の骨折・脱 臼は認めず，右椎骨動脈閉塞を認めた。また MRIの T2WI で頚椎棘突起周囲に血腫，椎体前方の軟部組織 損傷に伴う fluid, STIR で頸髄 C6 レベルの高信号を 認めた。この時点で明らかな骨折や脱臼を認めなかつ たが，不安性の否定ができなかったため軟性装具装着 で受傷後 7 日を目処に動態撮影を予定した. 受傷後 32 時間後から, 改善傾向であった上肢徒手筋力テス ト 2 以下と麻痺の進行を認めた. 再度 MRI を撮像し たところ T2WI で頝椎 C5/6 の前方脱臼を認め, 同部

\footnotetext{
* 長崎大学病院外傷センター

** 長崎大学病院整形外科
} 


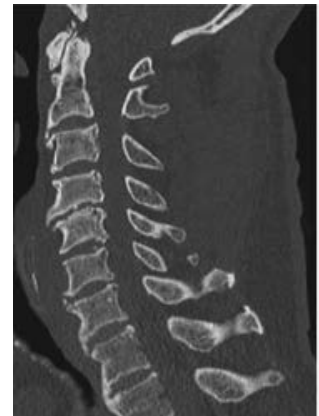

a

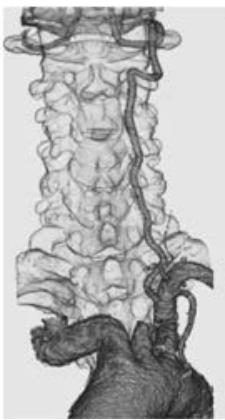

$\mathrm{b}$

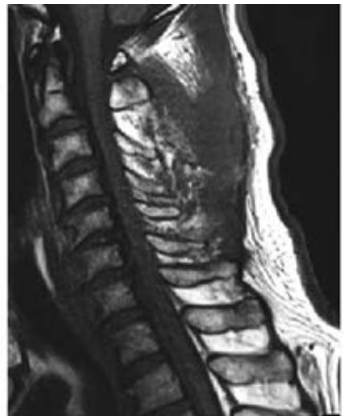

$\mathrm{c}$

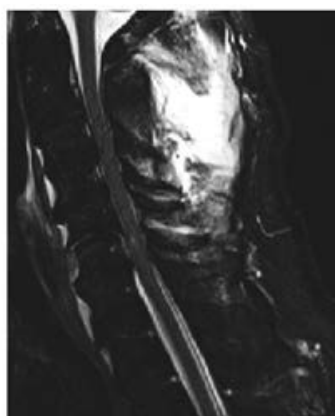

$\mathrm{d}$

図 1 a. CT. 骨折・脱臼を認めない.

b. 造影 CT. 右椎骨動脈閉塞を認める.

c. MRI T1WI. 难椎棘突起周囲に皮下血腫を認める.

d. MRI STIR. 椎体前方の軟部組織損傷を認める. C6 レベルの頸髄高信号を認める.

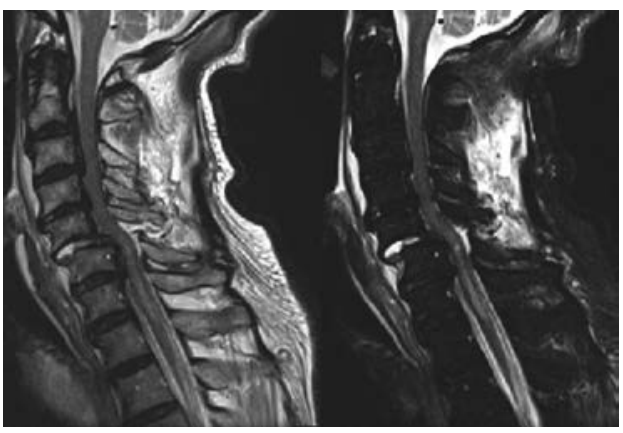

a

図 2 a. MRI T2WI. C5/6 の前方脱臼を認める.

b. MRI STIR. C5/6 の椎間板損傷を認める. 前方脱臼に伴う高度狭窄を認める. C6-8に 頸髄高信号を認める.

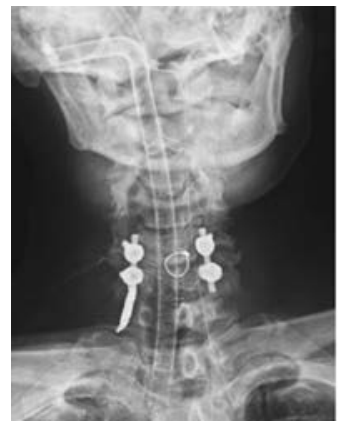

a

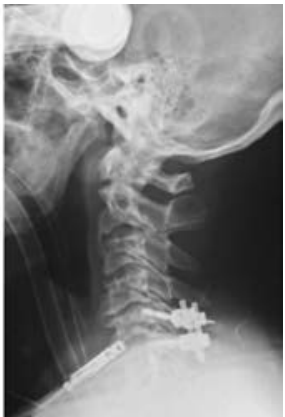

b

図 $3 a ， b$. 単純 X 線. 頚椎後方固定

位に脱臼を伴う高度狭窄と，頸髄の高信号の拡大を認 めた．同日初診時に指摘された右椎骨動脈閉塞の塞栓 術を行った後, 残存する不安定性に対して頝椎後方固 定術を行つた．術後は明らかな麻痺の増悪はなく転院 となった.

$$
\text { 考察 }
$$

頚椎損傷の診断遅延の原因として『不十分な画像検 索』, 『不適切な画像診断』が報告されている11. 前者 には $\mathrm{CT} ・ \mathrm{MRI} ・$ 動態撮影の不足，後者には判読医の 誤診がある.さらに不適切な画像診断として井上らは 変性疾患による変性を外傷性による変性と判断してし まうこと市などを報告している，また本症例に限らず 頚椎損傷の診断を難しくする原因として下位䅡椎が側 面像で肩と被ること, 頭頸部の鈍的外傷直後では頸部 硬直が強く肩が挙上するため評価に值する側面像を撮 影することが困難であることなどが挙げられる.さら に生熊らは救急現場での頝椎疾患が見逃され易い状況 として多発性脊椎損傷や重篤な合併症あるいは意識障

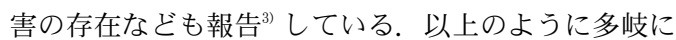
わたる頝椎損傷の診断遅延となりうる要因があり, 今 回我々は CT・MRI を行ったが，頝椎脱臼と診断す ることが困難であった.このような $\mathrm{CT}$ や $\mathrm{MRI}$ といっ た十分な画像検索" を行ったが, 後日脱臼や亜脱臼を きたした症例 ${ }^{310)}$ は本邦で少なからず報告されており 不安定性の評価が必要である。本症例は頭頂部の挫創 という受傷機転から䅡椎屈曲伸延型損傷が疑われ，明 


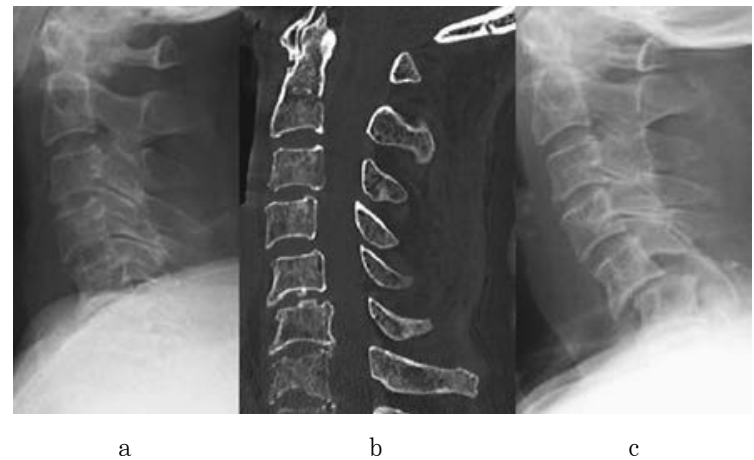

図 4 a. 単純 X 線. 伸展位（臥位）

b. CT. 伸展位（臥位）

c. 単純 X 線. 中間位 (座位)

らかな脱臼・骨折の指摘はできなかったが MRI での 軟部組織損傷や勒帯損傷・造影 CT での右椎骨動脈閉 塞から頝椎の不安定性を認識していた，そのため頝椎 硬直が改善していると考えられた受傷後 7 日後を目処 に動態撮影としていたが，この経過観察中に脱臼を認 めてしまった. 本症例の様な䅡椎屈曲伸延型損傷は後 方勒帯の損傷を基本として骨傷を伴わず，軽症例では 脱且が整復されてしまう ${ }^{8)}$ ことがあり， CT・MRIの 頭部が伸展位で固定された状態で検査を行うことが脱 曰をマスクさせたと考えられた．図 4 のように伸展位 ではアライメントが一見正常のように見えるが，中間 位では C $5 / 6$ に前方脱臼を有する症例も存在するた め，動態撮影が有用性であることがわかる．また多く の諸家から椎骨動脈閉塞は頚椎脱臼や骨折に伴 $5^{5-7111}$ ことが報告されている．特に脱臼に伴う椎骨動脈損傷 の発生率が高く．本症例においても右椎骨動脈閉塞は 頝椎脱臼という不安定性を示唆する所見の一つである と推察された. 以上のことから脱臼を認めない不安定 性のある症例では脱且が伸展位でマスクされてしまう 可能性があることを念頭に置き，可及的早期に動態撮 影を行うべきである. CT・MRI で骨傷を認めない不 安定性のある症例は受傷早期に何らかの評価が必要 とされるが，明確な診断指針がないのが現状である. 受傷早期での動態撮影にはさまざま見解があるが, Chang らは急性外傷に伴う頚椎の不安定性の評価と して動態撮影の有用性を報告している ${ }^{13)}$. 当院では本 症例を経験して可及的早期の自然下垂での動態撮影を 有用と考え，医師同伴のもと，意識があれば麻痺の進
行が起きていないかを本人と確認しながら撮影し，意 識がなければ，臥位で頸部に枕を入れ軽度屈曲位とな るようにして撮影を行っている．頝椎損傷すべてに動 態撮影を行うことは，医療費や被爆の観点からも不要 であるため，脱臼を認めない不安定性のある症例に 限って動態撮影を行うべきである. 今後も不安定性の 評価に関しては多くの症例から検討する必要性があ り，颈椎損傷の診断には受傷機転や画像所見を正確に 判読し, 难椎の不安定性を可及的早期の動態撮影で評 価することが大事である.

\section{参 考 文 献}

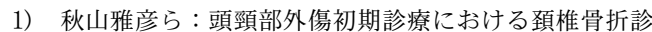
断遅延. 春髄外科, $26(1): 92-94,2012$.

2) Daffner, R.H., et al. : ACR appropriateness Criteria on suspected spine trauma. J. Am. Coll. Radiol., 4(11) : 762-775, 2007.

3）生熊久敬ら：診断の遅れた多発外傷に合併した頝椎脱 白骨折の 1 例。中四整会誌， 20 (1) : 151-158, 2008.

4）井上三四郎ら：見逃された䅡椎損傷. 骨折，33(2)： 337-340, 2011.

5) Louw, J. A., et al.: Occlusion of the vertebral artery incervical spine dislocations. J. Bone Joint Surg. Br., $72(4)$ : 679-681, 1990.

6) Mueller, C. A., et al.: Vertebral artery injuries following cervical spine trauma: a prospective observational study. Eur. Spine J., 20(12) : 2202-2209, 2011.

7) Nagata, K., et al.: Direct damage to a vertebral artery better predicts a vertebral artery injury than elongation in cervical spine dislocation. Acta Med. Okayama, 71(5) : 427-432, 2017. 
8）中尾弥起ら：頚椎屈曲伸延型損傷に対する手術的治療 線略. Neurosurg. Emerg., 18：60-64, 2013.

9） 日本外傷学会外傷初期診療ガイドライン改定第 5 版編 集委員会：改訂第 5 版 外傷初期診療ガイドライン JATEC, p.67. 東京, へるす出版, 2018 .

10）巽 政人ら：初診時に診断が困難であった䅡椎脱臼の 1 例. 整形外科, $61: 625-627,2010$.

11) Willis, B.K., et al.: The incidence of vertebral artery injury after midcervical spine fracture or subluxation. Neurosurgery, $34:$ 435-442, 1994.

12）山本啓雅ら：受傷時に発見できなかった頚椎脱臼骨折 の検討. 中部整災誌，42：927-928，1999.

13) Yeo, C. G., Jean, I., Kim, S. W.: Delayed or missed diagnosis of cervical instability after traumatic injury : usefulness of dynamic flexion and extension radiographs. Korean J. Spine, 12 (3) : 146149, 2015. 